\title{
“NO PIRACY TALK”: HOW ONLINE BRAND COMMUNITIES WORK TO DENORMALIZE CONTROVERSIAL GAMING PRACTICES
}

Purpose: The purpose of this study is to explain how online brand communities work to support the denormalization of controversial (i.e. illegal yet normalized) gaming practices.

Methodology: This qualitative study was characterized by long-term immersion in an online brand community for Brazilian Xbox gamers. The dataset includes online and offline interactions with community members, interviews, and online archival data.

Findings: This study shows how online brand community members promoted legal gaming in a market where piracy was prevalent. It demonstrates how community members worked to establish coherence; engaged in cognitive participation; developed collective action that extended beyond the community; and reflected on their own work.

Research implications: This study identifies online brand communities as a potential ally in combating controversial practices in online gaming; complements individual and behavioral approaches in explaining why consumers adopt controversial practices in online environments; and adds a normalization framework to the toolkit of Internet researchers.

Practical implications: This study identifies ways in which the potential of online brand communities can be leveraged to reduce consumer adherence to controversial gaming practices through denormalizing these and normalizing alternative practices that may be more desirable to companies and other stakeholders.

Originality: This long-term, qualitative study inspired by Normalization Process Theory offers an innovative perspective on the online practices of consumers who engage with a brand in ways that create value for themselves and for the brand.

Keywords: Normalization, illegal gaming, online brand community, piracy

To cite this article: Scaraboto, D., Almeida, S. and Fleck, J. (2020), "“No piracy talk”: how online brand communities work to denormalize controversial gaming practices", Internet Research, Vol. ahead-of-print No. ahead-of-print. https://doi.org/10.1108/INTR-12-2018-0529 
Illegal consumption practices are widespread in online and video game playing. These include "theft, fraudulent activities, robberies, counterfeited documents, assault and batteries, threats and illegal gambling cases” (Chen et al., 2005, p. 247). Practices such as assault and threats are unequivocally detrimental to gamers and industry alike. Other practices, such as piracy, are more ambiguous and may lead to positive outcomes at times, including increased legal consumption through the successful conversion of illegal users into paying users (Teng et al., 2012; Yu et al., 2015; Van der Ende et al., 2015). Such ambiguity and the fact that those who engage in piracy perceive it "not as theft, but as normal, commonplace, and unadventurous" behavior that is interwoven with online sharing routines (da Rimini and Marshall, 2014, p. 326) mark piracy as an illegal practice that is normalized. As such, piracy generates heated public discussion and disagreement across multiple segments in society, which are characteristic of a controversial practice.

Most extant research that sheds light on the existence and persistence of piracy (e.g. Siponen et al., 2012; Yoon, 2011; Yoon, 2012) is of limited value for understanding controversial gaming practices because it explains individual-level, not aggregate-level, commitments to engage or not in such practices. These studies employ several theoretical models (see Yoon 2012 for a review), to explain individuals’ behavioral intention to commit piracy or engage in other illegal gaming practices (Yoon, 2012; Taylor 2012; Lin et al., 2013), yet do not account for the sociocultural structures in which gamers are engaged, and which may influence the widespread adoption and normalization of illegal gaming practices (Yu et al., 2015). A more nuanced view “of the wider context in which digital piracy takes place” has been called for (Holt and Brown, 2018, p.7), and our study addresses this gap in Internet research.

We draw from a vast stream of research on brand communities which demonstrates that engaged consumers can attract other actors in the market and convince them to change their 
viewpoints and behaviors regarding brands, companies, or market practices, positively or negatively (e.g. Pendarvis 2016; Scaraboto et al., 2012). As noted by Cova and Dalli (2009, p. 322), “social, proximate communities are more effective and influential regarding people’s behavior than either marketing institutions or other formal cultural authorities”. Thus, social contexts such as gaming communities (Hsiao and Chiou, 2012) may influence the widespread adoption - or rejection - of specific gaming practices.

Yet limited research has been undertaken to examine the role of brand communities in increasing or reducing engagement in controversial gaming practices (Pendarvis 2016). In particular, we lack knowledge of how brand communities may contribute to reducing widespread engagement in (i.e. denormalizing) a controversial gaming practice such as piracy. This article addresses this gap through an extended qualitative study of a brand community against piracy in in the Brazilian video game market. Specifically, this study asks: how can online brand communities denormalize controversial gaming practices?

Addressing this question is important, as this can help Internet researchers to move beyond primarily individualistic views of what motivates consumers to adopt controversial gaming practices and to examine some social and contextual aspects that motivate consumers to quit these practices or not adopt them in the first place (Seo et al., 2015).

This study draws on an in-depth cultural understanding of the Brazilian video game market and adopts a theoretical framework based on Normalization Process Theory (NPT) to examine the denormalization of piracy in that context. NPT cuts across individual and collective levels of analysis and directs researchers' attention to the work undertaken by individuals and collectives to promote social change. Transformation, from an NPT perspective, is achieved through the intentional normalization of new practices which, as they are normalized, may generate tensions or denormalize other practices that were initially in place (Knowles et al., 
2013). NPT focuses on what actors do to implement a practice, rather than on their attitudes or decision-making processes (Rettie et al., 2014). Despite the potential of NPT for examining how multiple actors work, individually and collectively, to disseminate desirable practices and eradicate detrimental or controversial ones, Internet marketing researchers have not yet exploited this theoretical framework.

This study’s findings retrace the historical development of a brand community of gamers to illustrate how mechanisms of normalization (establishing coherence for a common goal, cognitive participation, collective action, and reflexive monitoring) were employed by consumermanagers, moderators, and early community members to denormalize piracy and simultaneously normalize legal gaming among Brazilian gamers. As these mechanisms are employed, a shared sense of moral responsibility emerges, spreads, and is disseminated in the community, making it an active space of resistance to controversial gaming practices. After presenting these findings, we discuss their implications for Internet research.

\section{LITERATURE REVIEW}

How brand communities may promote change in consumption practices

In marketing and consumer research, online communities can be understood broadly as social networks of people with common interests (Hollebeek et al., 2017; Schau et al., 2009), which frequently revolve around brands of consumption activities. Existing research that looks at consumers' motivations to participate in brand communities focuses mostly on aspects related to intrinsic enjoyment and self-promotion among other personal rewards (e.g. Brodie et al., 2013). As an exception, Berthon et al. (2008) noted that some consumers may engage in brand-related activities online to change others' perceptions about the focal brand, that is, to have a specific effect on a target audience. Similarly, in a recent and comprehensive analysis that extends the 
understanding of online brand community engagement, Baldus et al. (2015, p. 981) explore other motivations consumers may have to join and engage with brand communities, including the search for like-minded peers; the feeling of connecting "to some good thing bigger than themselves"; the desire to help other community members; and a community member's desire to influence the brand.

Brand community members can be involved in the development and testing of new products (e.g. Pitta and Fowler, 2005), or can produce valuable outcomes that have market-level implications (e.g. Hakala et al., 2017). As noted by Cova and Dalli (2009, p. 321), consumers who create and manage online communities become empowered and "can manipulate and even produce special spaces within the market in which they can construct their cultural (consumer) identity”. In other words, seriously engaged consumers such as community-managers (Almeida et al., forthcoming) can promote market-level change. As they advance their own life projects, these consumers mobilize and reinterpret value propositions made by brands and companies while simultaneously further associating themselves with these company-provided resources (Cova and Dalli, 2009), searching for congruity between consumers' self and the brand values (Islam et al., 2018).

Brand community members can also formally or informally attract other actors in the market and convince them to change their viewpoints and behaviors regarding brands, companies, or market practices, positively or negatively (Scaraboto et al., 2012). Ultimately, this stream of research supports the understanding that brand communities may play an important role in promoting changes in consumer practices (Cova and Dalli, 2009). More specifically, this research suggests that brand communities can potentiate consumer involvement in anti-piracy work through building connections among consumers and fostering a shared sense of moral responsibility toward the brand and the community to which they feel they belong (Muñiz and 
O’Guinn, 2001). As noted by Yu et al. (2015), social pressure can influence individuals to follow or break rules. In that sense, brand communities with a commitment to legal gaming can work to create a deep feeling of belonging and a social pressure to restrict gaming consumption to original products. If this influence extends beyond the individual level, it may defend the brand against negative practices (Hassan and Ariño, 2016) and promote market-level change (Cesareo and Stöttinger, 2015; Pendarvis, 2016).

\section{Controversial online gaming practices}

As a consumption domain with several social and cultural implications (Crawford et al., 2011), gaming can become controversial when players engage in illegal or morally questionable practices. Most research examining controversial gaming practices focuses on individual player behaviors that are potentially damaging to the individuals themselves (such as addiction), or to other players, including account theft and fraud (Chen et al., 2005), bullying, cheating, and hoarding (Teng et al., 2012). As an exception, looking to understand the process through which new or emergent practices gain legitimacy within consumption communities, Pendarvis (2016) examined how controversial user-created modifications (i.e. modified game accessories, or "mods") were legitimized in the Call of Duty gamming community. Even though such gaming practices, individual or collective, are detrimental to individuals and society, they are widespread and often normalized in gaming contexts (Ditch the Label, 2017). Players who adopt negative gaming practices frequently rationalize their offensive behavior and discount the damage caused by their practices (Siponen et al., 2012).

Piracy in particular is a controversial gaming practice because it has proven positive effects in certain markets (Van der Ende et al., 2015; Holt and Brown, 2018), all the while leading to global losses of billions of dollars for the gaming industry and threatening the survival 
of companies that develop games (Business Software Alliance, 2011). Moreover, rationalization discourses are particularly effective in explaining piracy (da Rimini and Marshall, 2014), and formal sanctions seem to have little deterrent power over piracy intentions (Siponen et al., 2012).

To eradicate piracy, online gaming companies tend to work alongside legislators and distribution partners. Addressing consumers directly and enlisting consumers in fighting against piracy are perceived as less effective strategies (Kwong et al., 2003). However, eradicating piracy cannot be accomplished without addressing the consumer demand for pirated goods (Cesareo and Stöttinger, 2015). Prior research suggests that enlisting consumers in the fight against fake products can be very effective, as consumers who are deeply engaged with the brand have opportunities to participate in the "co-creation and diffusion of anti-counterfeiting campaigns" (Cesareo and Stöttinger, 2015, p. 532). A proven way to engage these consumers in campaigns against piracy is to appeal to "the intrinsic motivations of brand lovers - the pleasure they personally get from supporting their favorite brand” (Cesareo and Stöttinger, 2015, p. 534). Aligning these insights with the brand community literature, we note that brand communities may potentiate consumer involvement in anti-piracy measures as well as influence consumer adoption of controversial gaming practices.

\section{THEORETICAL FRAMEWORK}

Normalization Process Theory

As described by Rettie et al. (2014, p. 13), social normalization is "a social process in which ideas, behaviors, products and practices that are initially considered as outside the range of normality, gradually become accepted as standard, normal, and part of ordinary life.” NPT has been developed to support our understanding of how certain practices get deliberately normalized (i.e. routinized) and others not in everyday life and social contexts (May and Finch, 2009). 
Practices refer to "things that people do to perform certain acts and meet specific goals” (May and Finch, 2009, p. 539). Importantly, NPT considers that "human action is not assumed to be reducible to individual factors [...], and [...] that the contribution of both individuals and groups to the processes that lead to implementation, embedding, and integration are interdependent” (May and Finch, 2009, p. 540). This theory is descriptive, and it has mostly been applied to understanding the implementation of new technologies and practices in health industries (McEvoy et al., 2014). Nevertheless, consumer researchers have also explored its potential to explain how "new activities and products that are initially seen as different, and as outside normal behavior, can eventually become mainstream and accepted as normal” as well as how "other behaviors, which have been mainstream everyday ways of doing things, can become marginalized over time” (Rettie et al., 2014, p. 9). We believe NPT’s theoretical toolkit can be invaluable to Internet marketing scholars interested in examining user-driven changes in online practices, and to policy makers and marketing practitioners who are looking to implement change.

According to May and Finch (2009), the key assumptions of NPT include the following:

1. To understand the embedding of a practice we must look at what people actually do and how they work.

2. The production and reproduction of a practice requires continuous investment by agents through time and space.

3. The implementation of a practice happens through four mechanisms: coherence, cognitive participation, collective action, and reflexive monitoring.

a. Coherence is the individual and collective sense-making work that people do when they are faced with the problem of operationalizing a practice. Coherence is achieved by unpacking the components of a practice and differentiating it from 
existing ones. For instance, in the early days of online gaming, consumers engaged in individual and collective sense-making work to determine how pirated and original consoles would interact with online platforms and shape the multiplayer gaming experience. Questions such as "if I play with an original console, but a fake account on Live am I playing original or pirate?” are characteristic of coherence work.

b. Cognitive Participation is the relational work that people do to build and sustain a community of practice around a new technology or complex intervention. Gamers may work to initiate an anti-piracy movement, recruit members to join the movement, work to achieve legitimacy among other actors in the marketplace, and jointly elaborate a set of actions and procedures that need to be implemented to achieve the movement's goal.

c. Collective Action is the operational work that people do to enact a set of practices. For online gamers attempting to combat piracy and disseminate legal gaming, this mechanism involves finding ways to preserve their commitment on a daily basis and jointly figuring out how to keep each other accountable, as well as reassuring each other that the adopted practice is the best alternative.

d. Reflexive Monitoring is the appraisal work that people do to assess and understand the ways that a new set of practices affects them and others around them. This involves collecting information about the effects of the newly adopted practices, evaluating these effects individually and collectively, and attempting to redefine procedures or modify practices themselves.

Following May and Finch (2009), we adopted NPT as a sensitizing device that directed our data analysis to the collective discursive and practical work of the brand community for Xbox 
players. We mapped NPT concepts onto our dataset to identify how the community worked in combating the prevalent practice of piracy and disseminating legal gaming at the turning point when offline video games were taken online through the launch of the online multiplayer Live Platform by Microsoft Xbox.

\section{RESEARCH CONTEXT}

The Brazilian video game market

Whereas a broader analysis of how digital piracy became normalized is beyond the scope of this study (see da Rimini and Marshall, 2014 for such a discussion), we briefly review the origins of piracy among video game players in Brazil in order to set up the context for our analysis of its denormalization. The culture of piracy in the Brazilian video game market dates to the late 1970s, when Brazil was under a military dictatorship and the importation of consumer goods was heavily restricted. At that time — and over many years — illegally imported consoles co-existed with alternative versions of famous consoles produced in Brazil, so Brazilian gamers were able to play games from abroad. As both illegal imports and counterfeit consoles violate legitimate consumption practices, the entirety of the market was pirate (RedBull, 2016).

Piracy increased when Panasonic and Sony officially entered the Brazilian market with innovative CD-based video games. It was easier to copy CDs than cartridges. At the time "[i]t was common to find stands selling pirate games in every corner, even on public markets [...]. Consequently, many people who had abandoned video games because of the high prices of the 8and 16-bit cartridges started to return to the market” (Reche, 2018, np).

The average middle-class Brazilian teenager — who comprised the core market for CDbased games — justified engaging in piracy as a matter of affordability (Siponen et al., 2012), thereby contributing to normalizing piracy in the country. This normalization of piracy happened 
organically and was not led by any specific group or brand community. As most of the market was offline then, few opportunities existed for players to meet or play together, and discussions of video games happened mostly in small friendship circles (RedBull, 2016).

The culture of piracy continued through the next generation of consoles launched around 2000, when Sony released the PlayStation 2 and Microsoft entered the video game market by releasing the first Xbox, which has never been released officially in the Brazilian market. Consumers bought Xbox consoles abroad and usually played with pirated CDs, arguing that the few original games available on the market cost as much as 18 times more than a pirated game.

In 2006, the so-called "grey market” of illegally imported products represented 80 percent of the Brazilian market for video games and 94 percent of its console market (Franco, 2009). Stores and street sellers openly commercialized pirated products, and consumers justified their purchase with arguments related to economic disadvantage, preferred value, or the lack of options. In 2004, a National Council to Prevent Piracy and Crimes against Intellectual Property was created (Brazil, 2014). Ultimately, changing the local market regarding the purchase and use of pirated versus official products requires a fundamental change in the values of Brazilian consumers (Glenny, 2008), as the practice was ingrained in the local gaming culture.

\section{Xbox Live Network for Piracy Prevention}

In an independent initiative, Microsoft was one of the first companies to face the challenge of piracy in the video game market when it released the Xbox 360. To prevent piracy for this console, Microsoft implemented a system that blocked modified, hacked or pirated consoles from connecting to Xbox Live, the online network that enhances the Xbox gaming experience by allowing users to play live with others.

In 2009, Microsoft stated: “All consumers should know that piracy is illegal and that 
modifying their Xbox 360 console violates the Xbox Live terms of use, will void their warranty and result in a ban from Xbox Live” (Choney, 2009). The Live Network had a total of 20 million users then, and it was estimated that over 1 million would had been banned due to piracy. The other 56 million Xbox consoles not connected to the Live Network were not affected by the measure. With Live, Microsoft needed to trace not only physical consoles, but also Live accounts and Gamertags, which users now could share and sell illegally.

In 2011, Microsoft began producing the Xbox 360 in Brazil. Cristina Palmaka, channel director for the Microsoft consumer, justified the decision: "We believe in the potential of the Brazilian market and we have a long way ahead of us” (Silva, 2011), foreseeing signs that the culture of piracy could be changed. In 2017, Brazil had 66.3 million video game players, generating US\$ 1.05 billion, and comprising the $13^{\text {th }}$ largest market worldwide (Matsuura, 2017). It is in this context that PXB, the anti-piracy brand community that is the focus of this study, was launched and developed.

\section{A brand community for Brazilian Xbox players}

Initially named Portalxbox, PXB was launched in October 2005 by three friends who shared similar values. Less than four years after its launch, PXB acquired an average of 450 new members weekly, reaching more than 130,000 members in 2012. To coordinate these members' activities, the community had around 10 volunteer moderators (although this number fluctuated through the years), in addition to the three consumer-managers. A selected group of 120 community members (called PXB Elite) had permission to publish editorial content in the community. Regular members could comment on these articles and interact on discussion forums. Most community members were male (91\%), and 55\% of the members were between 26 and 35 years old (Field notes, August 2008). 
PXB's main objectives were to provide information for Xbox consumers; to be a meeting point for the community of Brazilian players on Microsoft platforms; to become a reference for reviews and technical articles on Xbox and Xbox 360 in Portuguese; to spread the use of original games among users; and to serve as an intermediary in relations between manufacturers, distributors, and consumers (Field notes, I Forum PXB, April 2008).

PXB/Portalxbox grew steadily until early 2013, when it was closed due to technical and administrative difficulties faced by the founding members. A few months later, a new website for the community, now officially called PXB, was launched by two of the three original founders and a new manager, a previous moderator. This community is currently active, being now a fraction of the size that the community was in 2012, when it was the largest community for Xbox players in the Portuguese language. For consistency, the community is called PXB throughout this article.

\section{METHODOLOGY}

This qualitative study was characterized by long-term immersion, in a process similar to that adopted by Kozinets, Patterson and Ashman (2017, p. 665), who describe their ethnographic engagement with the focal topic of their study as "prolonged and deep”, with preparatory field research being “conducted online and in person, in bursts and during focused periods” over a large number of years, and encompassing “participation in and observational lurking” on the focal site through time.

For more than ten years (2006-2017), one of the authors intermittently observed, participated in, and collected data from the focal community. During this period, the other two authors sporadically participated in focused rounds of data collection and analysis. Throughout this longitudinal immersion, we adopted an interpretive research approach to collect and analyze 
data. By its very nature, interpretive research uses multiple methods, involving different forms of data collection, multiple studies, and data triangulation (Belk, 2006). The use of multiple sources of data collection such as "observation, interviews and recordings [leads] to a more valid, reliable, and diverse construction of realities” (Golafshani, 2003, p. 604), and to thematic saturation (O’Reilly and Parker, 2012).

Ethnographic fieldwork, including participant observation and interviews, was conducted between 2008 and 2017. Two of the authors attended two meetings of the PXB National Forum in 2008 and 2009, where 13 interviews with relevant actors in the community were conducted. This resulted in 15 hours of video, which were transcribed into 215 single-spaced pages of text, and edited as two 30-minute videographies. E-mail exchanges between one of the authors and the three community managers were carried through the years adding up to 100 e-mails. Naturally, this dataset covers more than the phenomenon this paper addresses. Nevertheless, this prolonged engagement with online gaming and the focal brand community gave each of the three researchers a detailed appreciation of the overall field.

To complement and update this dataset, in 2013 we interviewed two community founders again (MrAx and DH) and the new community manager (Raphael) for the first time. In 2017, new interviews with MrAx and Raphael were conducted. These five interviews generated 13 hours of recorded audio, corresponding to 200 pages of single-spaced text. Table 1 presents the profiles of our key informants, including those interviewed during ethnographic fieldwork that are quoted in the findings.

\section{INSERT TABLE 1 ABOUT HERE}

During the 2016-2017 period we also conducted extensive online archival data research, collecting data on the PXB community discussion forums, Facebook groups, specialized websites, and media outlets that covered Xbox-related news and developments. This data covered 
the development of the consumer-managed community from its launch (as Portalxbox) to the evolution of its current form as PXB and its early years in the new platform. At this stage, we searched the archives of PXB, PXB social media accounts, and media reports ${ }^{1}$ for 27 keywords related to piracy (e.g. piracy, pirate, fake, original, blocked, unblocked). This resulted in 1607 discussion forum threads, 15 social media topics, 28 media articles and one Wikipedia entry that were downloaded and saved for analysis. Upon close reading, we determined that 299 discussion forum threads were relevant to this study's research question in addition to the media articles.

Interviews, selected discussion threads, and articles (N=343) were classified in two groups: high and low relevance. All 74 documents that we considered highly relevant were independently coded by the three authors with the assistance of the qualitative data analysis software Atlas.ti version 8.0. The remaining documents were read but not coded. This initial coding was influenced by the research question, and identified patterns and contradictions in the dataset following conventional guidelines for interpretive research (Miles and Huberman, 1994, p. 62). The authors then conferred and agreed on a list of 81 codes related to legal and illegal gaming practices, but not, at this point, related to prior theoretical understandings of gaming practices or practice normalization. Examples of codes included “conversion to pirate” and “conversion to original”, “doing the right thing”, “individual decision”, “intolerance”, “feeling wronged”, "rumors”. The authors then reviewed and discussed the results and, iterating between the data and the literature, identified NPT as a theoretical framework that could help crystalize understanding of the anti-piracy work the community enacted through the years. As our choice of theoretical framework focused on NPT, two of the authors conducted an additional round of data

\footnotetext{
${ }^{1}$ The goal in extending the search beyond the community was to observe external views on piracy and piracy resistance. We collected online versions of media articles published in Brazilian outlets including popular and specialized press.
} 
analysis mapping the NPT concepts onto the dataset, identifying specific instances that were related to coherence, cognitive participation, collective action, and reflexive monitoring. Informed consent was obtained from all informants interviewed in this project, and the community founder's consent was obtained to observe and collect data within the community forums. For all online archival data collection, we followed Kozinets' (2002) ethical guidelines. For online quotations included in this article, real names and usernames have been redacted, and interviewees' names were replaced with pseudonyms to preserve the informants' anonymity to the largest extent possible.

\section{FINDINGS}

Sensitized to the tenets of NPT, and triangulating multiple data sources, we explain how community members work to normalize legal gaming by engaging in several activities summarized in four mechanisms: (1) establishing coherence, (2) cognitive participation, (3) collective action, and (4) reflexive monitoring. We note that these mechanisms do not necessarily

operate sequentially, nor are they chronologically related to any specific phase in the evolution of the community. Rather, they were continuously and iteratively enacted in the community by its managers and engaged members. As new members joined the community, many of them were imbued with the community's values and started working in normalizing legal gaming through these mechanisms. We explain each mechanism, illustrating them with several examples from our dataset (Table 2). Figure 1 summarizes the normalization process.

INSERT TABLE 2 ABOUT HERE

INSERT FIGURE 1 ABOUT HERE 
Establishing coherence: The common goal of a piracy-free community

In the early 2000s, another brand community for Xbox Brazilian players existed, called Brasil Xbox. At Brasil Xbox, members discussed everything game-related, whether legal or not. In 2004, that forum was hacked. Suddenly deprived of a space to engage with other Xbox fans, Xbox player DH recalls immediately calling his friend MrAx to suggest the creation of a new website, but one that would support "what was right and that could have an impact and make a difference” (DH, interview, 2013). With another friend on board, Dicco, the three players offered a partnership to the consumer-managers of the recently closed Brasil Xbox: "They said no, because there was no future there, and when we said that we wanted a website that was against piracy, they laughed at us” (MrAx, interview, 2013).

This episode suggests that an initiative to fight the culture of piracy, which was prevalent in the Brazilian video game market at the time, sounded implausible to other gamers. This is indicative of how normalized illegal gaming was in the country. Community founders worked to establish coherence for the new community by determining that a piracy-free space was worthwhile, and defending the meaning and relevance of legal gaming through the creation of such a space. The founders' belief that legal gaming was a worthwhile pursuit, supported them in the continued effort to establish coherence for the practice among early community members (Almeida et al., 2018; May and Finch, 2009).

A year after launching, PXB had nearly 2,000 registered users. The supportive environment established by the co-founders attracted other early members, most of whom shared the values espoused by the community managers: "I decided to check out the community, and in the first moments I realized it was something focused and serious” (PS, moderator, videography interview, 2009); “On UOL and other forums, I felt like the old guy, the old uncle. I don’t want 
to be nobody’s uncle, so I stayed on PXB, where I felt connected to people” (Tux, moderator, videography interview, 2009); “Most of them [original members] were excellent gamers, so I felt at home” (Philip, moderator, videography interview, 2009).

Some of these early members assumed moderating responsibilities or became part of the PXB Elite group (thereby creating and posting content, and filtering content created by other members). Thus, in a process similar to that identified by Muñiz and O’Guinn (2001) in offline brand communities, legitimation of the community and the practices it upheld manifested itself in interactions among members, ultimately promoting a sense of shared moral responsibility: PXB users started to perceive themselves as "us” against “others” - — thereby opposing those who engaged in illegal gaming practices.

In 2009, when Microsoft implemented banning from Live due to piracy, legal gaming became more attractive to other consumers and the group engaged in coherence work once again to make sense of how to operationalize legal gaming in the online platform. Gamers looking for original games and fair playing found in PXB support and a place to congregate, and were more open to understandings of piracy and legal gaming that were different from the norm:

"From then on, we started to notice changes in community behavior, which was one of the coolest things PXB could contribute to. [...] PXB made available a lot of information for users. It started with tips about games, and then the community grew stronger and stronger because people came to us wanting to know more about non-pirated games” (Raphael, interview, 2013).

As noted by Raphael, a moderator turned administrator, incoming members attempted to fit into the community by learning about its meanings, sharing experiences, and interacting with established actors in this social context. As May and Finch (2009, p. 543) note, such internalization activities contribute to "embedding by anchoring the practice in the lived 
experience of individuals” and are an important aspect of establishing coherence. Through socializing in the community, incoming members were internalizing the same beliefs that motivated its founders. Nevertheless, what is piracy and what is not was a constant matter of debate in the community, demonstrating that establishing coherence required continuous work.

\section{Cognitive participation: Deterring rationalizations of piracy}

Cognitive participation is relational work. As such, it develops through interactions among community members, and between community members and other gamers. Dedicated community members favored discussions of topics aligned to the values of PXB, and moderators were strict in banning users who attempted to introduce piracy-related topics. As the community grew, fewer members were connected closely to the founders or necessarily shared these baseline values with them. Hence the initial work of cognitive participation at PXB consisted in preventing the proliferation of discussions that were against the normalization of legal gaming practices. MrAx recounts how the founders intensively engaged in this process during the early stages of PXB: "We invested much time logged on, to supervise, because for every person who got it right, we had 10 people who got it wrong. So, we needed to moderate and bring people to moderate with us” (MrAx, interview, 2013).

Each question about piracy that was posted on the community forums was quickly followed by a series of replies such as the following: "Piracy is a crime, that is, an unlocked console is illegal... if that is not enough for you, by being banned from Live you lose $40 \%$ of the experience that the Xbox offers, plus you will need tons of money to update the unlock and the console is more likely to have problems! Buy a locked console and be at peace!” (PXB forums, 2011).

By offering a mix of reasons not to engage in piracy in posts similar to the one above, 
members subverted the arguments gamers had to engage in piracy (affordability, better gaming experience through a wider variety of games), appropriating them as reasons not to engage in piracy. Through constantly enacting cognitive participation, committed members discussed, questioned, and pushed the fuzzy boundaries of piracy to enlighten others regarding this controversial gaming practice, aiming at making gamers assume responsibility and work to normalize the new practice. Committed members worked to socialize new members in the antipiracy community, and to recruit new gamers that would play original rather than pirated games.

\section{Collective action: Advancing toward legal gaming through collective effort}

When incoming members searched for opinions and information on how to abandon piracy to play with original games and locked consoles, several PXB members shared their tales of conversion, presenting the practice of legal gaming as the superior choice not only within the community, but also in the gaming world in general. These players mentioned that they had used unlocked games in the past, or confessed to having seriously considered buying them. Similarly, when incoming members wrote about their efforts to keep gaming legally on the forums, others came in support: "Congratulations on your attitude, you are the living proof that even with financial compromises and little money one can stay on the side of legality and enjoy it a lot” (PXB forum, 2009). "You are special, you are part of those who took the right path and made a difference in the gaming world. You don't need to be part of the rabble that steals others' properties” (PXB forum, 2012).

Tales of conversion into a "good gamer" or to "the good side of the force" were frequent on the PXB forums. This goal-orientation through conversion or reinvention shows efforts invested in normalizing legal gaming practices in accordance with the collective action mechanism proposed by May and Finch (2009). These stories underscore several positive 
sentiments associated with abandoning piracy for playing legally, such as peace of mind and enjoyment: "When I had my PSD 2 unlocked I jumped onto the piracy underworld [...] I can’t deny I had a good time, but I regret that. I could play a lot of games, but at the same time I gave little value to a game, I soon had to play another one [...] From Xbox 360 I started to play only originals and I'm happier with my consciousness” (PXB forum, 2017). "If you buy original games it compensates you in fun, tranquility, appreciation, you enjoy $100 \%$ of what you like”.

Overall, beyond merely reporting on their own conversion tales, PXB members attempted to support others in abandoning piracy by helping them overcome barriers in the adoption of legal gaming, and by integrating the new practice within the online social gaming context. This mechanism resembles the value-creating practices of evangelizing and justifying identified by Schau et al. (2009) in other brand communities. Here, however, converting extends beyond community management, since its members clearly aimed at convincing other members to change their own gaming practices, beliefs, and values, proving the interactional workability of the community and working to normalize a new practice.

For example, in view of the high cost of original games, the PXB Elite team shared tips on how to keep using original products with lower costs through exchange-based tactics (Cesareo and Stöttinger, 2015). Soon many members started to share information on how to get original games for lower prices, such as sales promotions, or tactics such as buying a game a few weeks after its launch: “This attitude against piracy is good for the market to develop and grow [...]; this week on Black Friday there were games sold for [less than 10 dollars]” (PXB forum, 2016). As these interactions became more prevalent, PXB managers created a classified ads section on the forums that served as a second-hand market for community members. The exchanges in that section also worked to crystallize the opposition to piracy and operationalize the legal gaming practice through sharing and commercializing original games only. 
Another relevant impact of the anti-piracy normalization process that started in the community and spread to the mainstream gaming society is the development of the project "Fair Game” (“Jogo Justo” in Portuguese), in which Dicco, one of the original PXB community founders, was involved. During its first years, PXB was an important national hub for gamming discussion. In the 2009 Community National Forum, a community member, Momo, proposed that gamers unite to abolish the taxes previously imposed on the gaming industry in Brazil. At that moment, project “Fair Game” was born. The community offered its website to host the project and Dicco, who was the webmaster for the community, became the webmaster for the project as well (Alegretti, 2014).

Then, in 2011 and 2012, the project promoted “Fair Game Day”. In these events, with the aim of getting permanent tax reductions for gaming sales in Brazil, "Fair Game” asked large retail chains operating in Brazil (e.g. Walmart) to sell games at cost price, abdicating their profit to support the movement against illegal gaming. During “Fair Game Days”, the PXB community structure collapsed with increased traffic to its website. In an interview given to the press, Dicco mentions that even Walmart's website crashed due to the influx of gamers who were trying to purchase cheaper original games (Alegretti, 2014).

"Fair Game” aimed at lowering the taxes on games that existed in Brazil at the time. This initial project then evolved into an association, AciGames, which aimed to be a representative of the gaming industry and commerce in Brazil, investing in its development. Dicco took part in the association since its beginning, starting in the role of secretary in the first composition of its board. Currently, AciGames has three subsidiaries (in Argentina, Italy and the United States), and continues to operate in Brazil (ACIGAMES, 2018). As a result of this collective effort, in 2018 a proposal of tributary immunity for games produced in Brazil is under evaluation by the legislative houses in Brazil. Another option being considered is to reduce taxes from 72\% to 9\% 
for all games sold officially in the country (Santana, 2018).

Reflexive monitoring: the continuous evaluation of a piracy-free ideal

When Microsoft launched the Xbox 360 in Brazil, the PXB community avidly promoted the original console. In the view of community managers, this had an effect on the sales of original games in the local market: "The launching of games in Brazil [by Microsoft] came, and then the online platform [Xbox Live], and PXB had a fundamental role in all of that. We embraced the idea; we mobilized the community. We transformed and incorporated a number of users that Microsoft now can say it has in Brazil” (MrAx, interview, 2013). In that period, PXB was the largest Xbox community in Portuguese in the world, and alternated for several years, since 2008, between the first and the third position in Google search results for the most significant keywords related to the brand (i.e.: Xbox, Xbox 360, Xbox Brasil).

Independently of whether or not the community had a real impact on the sales of original consoles and games, having like-minded people working toward defending and promoting their brand during the launch of the console in a piracy-riddled market was, in itself, a positive outcome for Microsoft. Even though PXB was not affiliated with Microsoft Brazil, the company offered to host annual meetings for the community members' meeting in 2008 and 2009 at the Microsoft headquarters in São Paulo. DH attributes Microsoft's attitude to the valuable outcomes generated by the community: "We were doing it, we were evangelizing people, and we were teaching them [...] getting away from that culture of piracy [...], from that nagging feeling that we had that Brazil was a synonym for piracy. I think this was one of the reasons that made Microsoft look at our work and say: 'At least they are serious...”’ (DH, interview, 2013). The initial excitement the community founders felt can be attributed to their engagement in value-creating activities, but also to their reflection about the outcomes of their individual and collective work to 
normalize legal gaming through the community.

At the 2009 event, PXB launched an official campaign against piracy, "even though it was a philosophy they had adopted since the first day of the community” (DH, videography interview, 2009). This campaign manifested the community’s reflection on its own work, evidencing an important characteristic of the normalization process. At the event, community managers highlighted the relevance of developing consciousness against piracy. All community moderators were wearing t-shirts with statements against piracy during the events, and keynote speakers included community members, market experts, and even Microsoft managers who gave speeches against piracy, sharing information that would allow community members and other gamers to understand the importance and impact of their work.

PXB community members also worked to preserve and reconfigure their own normalization work. For example, a long-term member engages in conversation with a new moderator on how to engage with gamers who reportedly play illegally:

“I’d rather try to be more 'pedagogical', trying to show the positive side of originality and its advantages. Even though I'm aware of the difficulties many find in trying to stay original, I still believe that at the end of the day it is worth it. If I did not believe it, I would have already changed sides, and that thought has crossed my mind many times before.” (PXB member, discussion forum, 2012). By continuously reflecting on and discussing the work they individually and collectively pursue to normalize legal gaming, community members reinforce the normalization process.

\section{DISCUSSION}

Piracy is controversial because it still generates heated public discussion and disagreement, not only among actors in the video game market, but among different segments in society (da 
Rimini and Marshall, 2014). This study shows how a community of gamers worked to denormalize this controversial gaming practice in the Brazilian market. Its contributions are threefold.

First, this study contributes to the theorizing of controversial internet behaviors by complementing prior research that focused on consumers’ individual motivations to adopt controversial practices. Studies employing individual-centered models (e.g. Yoon, 2012) have highlighted the importance of individual beliefs, attitudes, values, and knowledge in determining the propensity to adopt a controversial gaming practice such as piracy. Our study shows how a gaming collective may intentionally work to shape such beliefs, attitudes, values, and knowledge, consequently leading to the denormalization of piracy. As such, our findings extend prior research on legitimation processes of contested practices in consumption gaming communities (Pendarvis, 2016). The four mechanisms of the normalization process identified in this study demonstrate how a collective of consumers works to shape normative beliefs, normalize practices, and institutionalize social norms among gamers in a market. As we unpack this process, we also observe the intertwining of collective and individual aspects by exploring how community members worked to denormalize piracy without losing their gamer identity. As the new practice of playing original games and consoles was normalized, a more positive identity for Brazilian gamers was established. This new identity was based on values gamers could be proud of, and has the potential to influence future generations of gamers to be morally responsible consumers (Giesler and Veresiu, 2014) rather than “pirates”. Our adoption of Normalization Process Theory (May and Finch, 2009) to highlight the collective aspects of consumer engagement in controversial gaming practices adds to the theoretical toolkit of internet researchers. NPT can be useful to examine the processes that lead to certain online practices being normalized and others not in a given market or field. 
Second, our findings extend our knowledge of the potential of online brand communities by demonstrating how the consumer-managers built and developed the PXB community to fight piracy and support the normalization of legal gaming practices in the Brazilian videogame market. We note how members' identification with the community raised a deep sense of moral responsibility toward the group, its values and goals, a known outcome of community engagement (Muñiz and O’Guinn, 2001). Enacting value-creating practices typical of online brand communities (Schau et al., 2009), members celebrated conversions, shared personal tales, and supported one another through the adoption of legal gaming practices. This aligned and committed group composed a safe base that, along with changes promoted by other actors in video game market in Brazil, assisted players in their transition from piracy to legal gaming practices. Continuous investments by the community worked to establish the understanding that switching from normalized piracy to legal gaming was feasible — and most importantly, was a good choice. We also show how committed members recruited others to join the effort of normalization, thereby extending the shared moral responsibility to a broader group of gamers. Although it would be difficult to measure the effects of the brand community efforts on the gaming practices of Brazilian players, the extensive qualitative dataset amassed in this study suggests that PXB had an impact on denormalizing illegal gaming and normalizing legal gaming practices that extended beyond the community boundaries. Hence, whereas prior research shows that online brand communities create value for brands and companies (Cova and Dalli, 2009), our findings suggest that PXB created value not only for the Xbox brand and Microsoft, but also for retailers, other brands (e.g. developers, competing consoles), and consumers who chose to adopt legal gaming.

Given that the focal brand community for this study was founded and managed by consumers, these findings demonstrate that having consumers in complete control of online brand 
communities does not necessarily mean that these communities will end up challenging corporations and opposing a brand's managing practices, as prior research suggested (Cova and Pace, 2006). Instead, we argue that online brand communities can work to reduce consumer adherence to certain controversial gaming practices and normalize others that may be more desirable to companies and other stakeholders.

Third, by explaining how a brand community combats piracy as a controversial gaming practice, we offer a contrasting case to that examined by Yu et al. (2015). While Yu et al. (2015, p. 318) explain how virtual communities are an open space for members "to engage in illicit sharing as an act of heroism based on social exchange behavior" by rewarding consumers who share resources (legally or illegally) with other members, our findings suggest that online brand communities may discourage members to engage in illicit and controversial gaming practices through similar social exchanges. Both studies, Yu et al. (2015) and ours, deal with young consumers and expensive desirable products (software and games), but while in Yu et al.'s (2015) study heroism is marked in the community by sharing illegal software that other members allege they could not buy (thus normalizing piracy), in our study a similar heroic role is performed by community managers and members who assist others gamers in finding ways to fully experience play without transgressing the limits of legality (denormalizing piracy). This finding has implications for companies that need to deter similarly illegal practices such as the counterfeiting of products. Fashion brands, for example, whose designer handbags constitute objects of desire and, as such, are frequently counterfeited, could mobilize brand communities to educate and inspire others in a market about the importance of acquiring original rather than counterfeit products. Companies may also consider collaborating with online communities in cocreating and promoting alternative ways of access to original products. Second-hand markets frequently emerge and flourish in online brand communities, and community members could 
have privileged access to subscription or consignment services. Such initiatives may add to community efforts and support the denormalization of piracy.

We see several avenues for future research to build upon our findings. For example, researchers can deepen our understanding of controversial practices by considering the differences in the denormalization process between practices anchored in physical products (such as handbags) and digital products (such as games). Another issue that merits further attention is the tight interplay between the denormalization of existing practices and the normalization of new ones. In our context, piracy and legal gaming can be seen as alternatives, but many gamers often incorporate both practices into their gaming activities. As noted by Knowles et al. (2013) the normalization process can lead to clashes between elements of the practice being normalized and the existing norms being opposed, exposing the tensions inherent in this dual process. Future studies could also be developed to determine effective strategies for brands who wish to collaborate with consumer-managers in developing brand communities for advancing specific normalization goals. Finally, the framework developed in this study could also be extended to contexts of collective anti-sociality on social media, such as online shaming on Twitter or Facebook. Research aiming at understanding the role of consumer collectives in normalizing antisocial behavior could support government and policy makers in combating illegal and damaging online practices, as well as in normalizing productive and beneficial Internet practices.

\section{REFERENCES}

ACIGAMES website (2018). “Inicial [Initial]”, available at: http://www.acigames.com.br/ (accessed 14 November 2018).

Alegretti, M. (2014), “Quem é este tal Malegra? [Who is this Malegra?]” Indústria de Jogos, available at http://www.industriadejogos.com.br/autor/ (accessed 03 July 2018). 
Almeida, S.O., Scaraboto, D., Fleck, J.P., and Dalmoro, M. (2018), "Seriously engaged consumers: Navigating between work and play in online brand communities”, Journal of Interactive Marketing, Vol 44, November 2018, pp. 29-42.

Baldus, B.J., Voorhees, C. and Calantone, R. (2015), “Online brand community engagement: Scale development and validation”, Journal of Business Research, Vol. 68 No. 5, pp. 978-985.

Belk. (2006), Handbook of Qualitative Research Methods in Marketing, Edward Elgar Publishing, Inc., Northampton.

Berthon, P., Pitt, L. and Campbell, C. (2008), “Ad lib: When customers create the ad”, California Management Review, Vol. 50 No. 4, pp. 6-30.

Brazil. (2014), "Conselho Nacional de Combate à Pirataria comemora 10 anos [National Council to Combat Piracy celebrates $10^{\text {th }}$ anniversary]”, Government of Brazil, available at: http://www.brasil.gov.br/cidadania-e-justica/2014/11/conselho-nacional-de-combate-apirataria-completa-10-anos (accessed 12 June 2018).

Brodie, R.J., Ilic, A., Juric, B. and Hollebeek, L. (2013), “Consumer engagement in a virtual brand community: An exploratory analysis”, Journal of Business Research, Vol. 66 No. 1, pp. 105-114.

Business Software Alliance. (2011), 2011 Piracy Study, available at: http://globalstudy.bsa.org/2011/ (accessed 12 June 2018).

Cesareo, L. and Stöttinger, B. (2015), “United we stand, divided we fall: How firms can engage consumers in their fight against counterfeits”, Business Horizons, Vol. 58 No. 5, pp. 527537.

Chen, Y., Chen, P.S., Hwang, J., Korba, L., Song, R. and Yee, G. (2005), “An analysis of online gaming crime characteristics”, Internet Research, Vol. 15 No. 3, pp. 246-261. 
Choney, S. (2009), “Microsoft bans up to 1 million Xbox Live users”, NBC News.Com, available at: http://www.nbcnews.com/id/33866696/ns/technology_and_science-games/t/microsoftbans-million-xbox-live-users/\#.WyBF60gvzIU (accessed 12 June 2018).

Cova, B. and Dalli, D. (2009), “Working consumers: The next step in marketing theory?”, Marketing Theory, Vol. 9 No. 3, pp. 315-339.

Cova, B. and Pace, S. (2006), "Brand community of convenience products: new forms of customer empowerment — the case 'my Nutella The Community’”, European Journal of Marketing, Vol. 40 No. 9/10, pp. 1087-1105.

Crawford, G., Gosling, V.K. and Light, B. (2011), Gamers: The Social and Cultural Significance of Online Games, Routledge, Oxon.

da Rimini, F., and Marshall, J. (2014), "Piracy is normal, piracy is boring: systemic disruption as everyday life”, Fredriksson, M. and Arvanitakis, J., Piracy: Leakages from Modernity, Litwin Books in association with GSE Research, pp. 323-344.

Ditch the Label (2017), Game Abuse: The Extent and Nature of Online Bullying within Digital Gaming Environments, available at: https://www.ditchthelabel.org/wpcontent/uploads/2017/05/InGameAbuse.pdf (accessed 12 June 2018).

Eckhardt, G. M., Houston, M. B., Jiang, B., Lamberton, C., Rindfleisch, A., and Zervas, G. (2019), “Marketing in the sharing economy”, Journal of Marketing, Vol. 83 No. 5, pp. 527.

Franco, P. (2009), “A nation of pirates”, The Escapist, available at: http://www.escapistmagazine.com/articles/view/video-games/issues/issue_201/6059-ANation-of-Pirates (accessed 12 June 2018).

Giesler, M. and Veresiu, E. (2014), “Creating the Responsible Consumer: Moralistic Governance Regimes and Consumer Subjectivity”, Journal of Consumer Research, Vol. 41 No. 3, pp. 
849-867.

Glenny, M. (2008), McMafia: A Journey through the Global Underworld, House of Anansi, Toronto, CA.

Golafshani, N. (2003), “Understanding reliability and validity in qualitative research”, The Qualitative Report, Vol. 8 No. 4, pp. 597-607.

Hakala, H., Niemi, L. and Kohtamäki, M. (2017), “Online brand community practices and the construction of brand legitimacy”, Marketing Theory, Vol. 17 No. 4, pp. 537-558.

Hassan, M. and Ariño, L.V.C. (2016), “Consumer devotion to a different height”, Internet Research, Vol. 26 No. 4, pp. 963-981.

Hollebeek, L.D., Juric, B. and Tang, W. (2017), “Virtual brand community engagement practices: A refined typology and model”, Journal of Services Marketing, Vol. 31 No. 3, pp. 204217.

Holt, T. J., and Brown, S. (2018), “Introduction”, Brown, S. and Holt, T. J. (Eds.), Digital Piracy, Routledge, London, pp. 1-12.

Hsiao, C.-C. and Chiou, J.-S. (2012), "The impact of online community position on online game continuance intention: Do game knowledge and community size matter?”, Information \& Management, Vol. 49 No. 6, pp. 292-300.

Islam, J.U., Rahman, Z. and Hollebeek, L.D. (2018), “Consumer engagement in online brand communities: a solicitation of congruity theory”, Internet Research, Vol. 28 No. 1, pp. 23-45.

Knowles, S. E., Chew-Graham, C., Coupe, N., Adeyemi, I., Keyworth, C., Thampy, H., and Coventry, P.A. (2013), “Better together? a naturalistic qualitative study of interprofessional working in collaborative care for co-morbid depression and physical health problems”, Implementation Science, Vol.8, No.110, pp.1-9. 
Kozinets, R., Patterson, A. and Ashman, R. (2017), “Networks of desire: How technology increases our passion to consume”, Journal of Consumer Research, Vol. 43 No. 5, pp. $659-682$.

Kozinets, R. V. (2002), “The field behind the screen: Using netnography for marketing research in online communities”, Journal of Marketing Research, Vol. 39 No. 1, pp. 61-72.

Kwong, K.K., Yau, O.H.M., Lee, J.S.Y., Sin, L.Y.M. and Tse, A.C.B. (2003), “The effects of attitudinal and demographic factors on intention to buy pirated CDs: The case of Chinese consumers”, Journal of Business Ethics, Vol. 47 No. 3, pp. 223-235.

Lin, T., Hsu, J.S. and Chen, H. (2013), “Customer Willingness to Pay for Online Music: the role of free mentality”, Journal of Electronic Commerce Research, Vol 14 No 4, pp. 315-333.

Matsuura, S. (2017), “Da pirataria ao bilionário mercado brasileiro de videogames [From piracy to the billionaire Brazilian videogame market]", Jornal O Globo, 13 October, available at: https://oglobo.globo.com/sociedade/tecnologia/da-pirataria-ao-bilionario-mercadobrasileiro-de-videogames-21941632\#ixzz5HkOjyJro (accessed 12 June 2018).

May, C. and Finch, T. (2009), "Implementing, embedding, and integrating practices: An outline of normalization process theory”, Sociology, Vol. 43 No. 3, pp. 535-554.

McEvoy, R., Ballini, L., Maltoni, S., O’Donnell, C.A., Mair, F.S. and MacFarlane, A. (2014), “A qualitative systematic review of studies using the normalization process theory to research implementation processes”, Implementation Science, Vol. 9 No. 1, p. 2.

Miles, M. and Huberman, A.M. (1994), Qualitative Data Analysis, 2nd ed., Sage Publications, London.

Muñiz, A.M. and O’Guinn, T.C. (2001), “Brand community”, Journal of Consumer Research, Vol. 27 No. 4, pp. 412-432.

O’Reilly, M. and Parker, N. (2012), ‘Unsatisfactory Saturation’: a critical exploration of the 
notion of saturated sample sizes in qualitative research, Qualitative Research, Vol. 13 No. 2, pp.190-197.

Pendarvis, N. (2016). The unwritten rules about breaking the rules: Collective frames and the legitimation of contested practices within consumption communities. Doctoral Dissertation in Business Administration. Darla Moore School of Business, University of South Carolina. Pitta, D.A. and Fowler, D. (2005), “Online consumer communities and their value to new product developers”, Journal of Product \& Brand Management, Vol. 14 No. 5, pp. 283-291.

Reche, R. (2018). "Videogames e Pirataria - A renovação da indústria de videogames no Brasil,” Fliperama de Boteco. Available at: http://fliperamadeboteco.com/videogames_e_pirataria/ (accessed 24 August 2019).

RedBull (2016). “Exclusivo: Assista à série ‘Paralelos’ [Exclusive: Watch the series 'Parallels']'”, available at: https://www.redbull.com/br-pt/serie-paralelos-narra-piratariade-games-no-brasil (accessed 23 August 2019).

Rettie, R., Burchell, K. and Barnham, C. (2014), “Social normalisation: Using marketing to make green normal”, Journal of Consumer Behaviour, Vol. 13 No. 1, pp. 9-17.

Santana, A.G. (2018), "Videogames e consoles brasileiros podem obter imunidade tributária” [Brazilian games and consoles can gain tributary immunity]”, Olhar Agro \& Negócios, available at:

http://www.olhardireto.com.br/agro/noticias/exibir.asp?id=25879\&noticia=videogames-econsoles-brasileiros-podem-obter-imunidade-tributaria-estamos-atrasados-em-decadasdiz-jogador-de-mt (accessed 12 July 2018).

Scaraboto, D., Rossi, C.A.V. and Costa, D. (2012), “How consumers persuade each other: Rhetorical strategies of interpersonal influence in online communities”, BAR - Brazilian 
Administration Review, Vol. 9 No. 3, pp. 246-267.

Schau, H.J., Muñiz, A.M. and Arnould, E.J. (2009), "How brand community practices create value”, Journal of Marketing, Vol. 73 No. 5, pp. 30-51.

Seo, Y., Buchanan-Oliver, M. and Fam, K.-S. (2015), “Advancing research on computer game consumption: A future research agenda”, Journal of Consumer Behaviour, Vol. 14 No. 6, pp. 353-356.

Silva, M.A.T. (2011), “Microsoft anuncia fabricação do Xbox 360 no Brasil [Microsoft announces Xbox 360 production in Brazil]”, XboxPlus, available at: http://www.xboxplus.net/microsoft-anuncia-fabricacao-do-Xbox-360-no-brasil-mdelo-4gb-custara-r-79900/ (accessed 12 June 2018).

Siponen, M., Vance, A. and Willison, R. (2012), "New insights into the problem of software piracy: The effects of neutralization, shame, and moral beliefs”, Information \& Management, Vol. 49 No. 7-8, pp. 334-341.

Taylor, S. A. (2012) "Evaluating digital piracy intentions on behaviors", Journal of Services Marketing, Vol. 26 Issue 7, pp.472-483.

Teng, C., Tseng, F., Chen, Y. and Wu, S. (2012), “Online gaming misbehaviours and their adverse impact on other gamers”, Online Information Review, Vol. 36 No. 3, pp. 342358.

Van der Ende, M., Poort, J., Haffner, R., Bas, P. de, Yagafarova, A., Rohlfs, S., and Van Til, H. (2015), Estimating displacement rates of copyrighted content in the EU, Publications Office of the European Union, Brussels.

Yoon, C. (2011), “Theory of Planned Behavior and Ethics Theory in Digital Piracy: An Integrated Model”, Journal of Business Ethics, Vol. 100 No. 3, pp. 405-417.

Yoon, C. (2012), “Digital piracy intention: A comparison of theoretical models”, Behaviour \& 
Information Technology, Vol. 31 No. 6, pp. 565-576.

Yu, C., Young, M.-L. and Ju, B.-C. (2015), “Consumer software piracy in virtual communities”, Internet Research, Vol. 25 No. 2, pp. 317-334. 


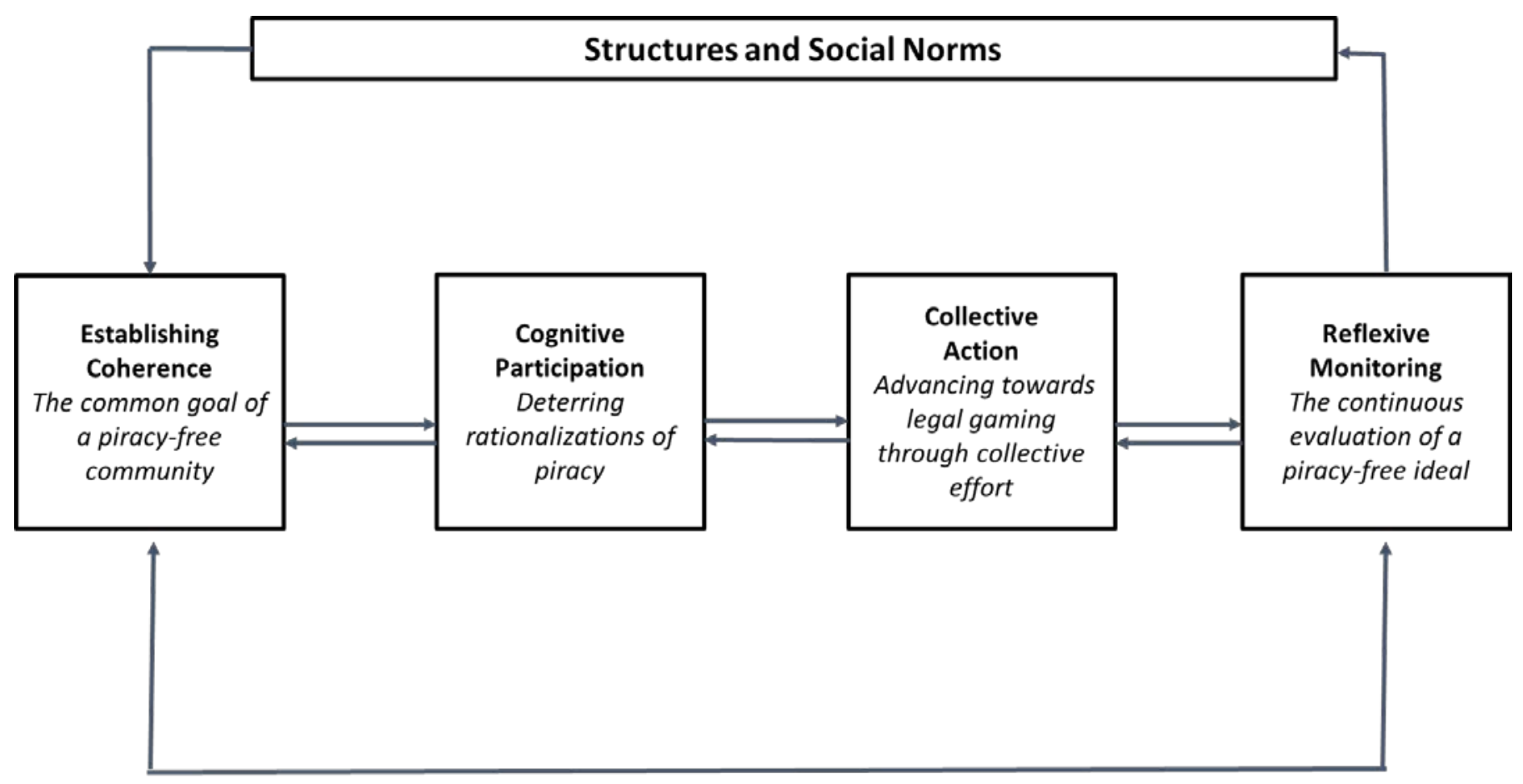

Figure 1 - The process of normalization of legal gaming in the Brazilian market 
Table 1: Description of informants

\begin{tabular}{|c|c|c|}
\hline $\begin{array}{c}\text { Informant } \\
\text { (Pseudonym, Age, Profession) }\end{array}$ & Community Roles & Contribution \\
\hline MrAx, 40s, medical doctor & $\begin{array}{l}\text { Community leading manager, } \\
\text { founder, public relations, and } \\
\text { mentor of the community growth. }\end{array}$ & $\begin{array}{l}\text { Videography interview, 2008/2009, } \\
\text { Interviews 2013/ 2017. Several e- } \\
\text { mail exchanges and informal } \\
\text { conversations all over the years. }\end{array}$ \\
\hline DH, late 40s, IT entrepreneur & $\begin{array}{l}\text { Commercial director and founder } \\
\text { of Portalxbox; performed several } \\
\text { roles, including supporting MrAx } \\
\text { in managing community on its } \\
\text { beginning. }\end{array}$ & $\begin{array}{l}\text { Videography interview, 2008/2009, } \\
\text { Interview 2013. E-mail exchanges. }\end{array}$ \\
\hline Dicco, early 40s, IT technician & $\begin{array}{l}\text { IT developer and community } \\
\text { founder, responsible for Portalxbox } \\
\text { platform until } 2012 \text {. }\end{array}$ & $\begin{array}{c}\text { Videography interview, 2008/2009. } \\
\text { E-mail exchanges. }\end{array}$ \\
\hline Raphael, 29, graphic designer & $\begin{array}{l}\text { Former moderator at community; } \\
\text { became a manager in } 2012 .\end{array}$ & $\begin{array}{l}\text { Interviews 2013/2017. } \\
\text { E-mail exchanges. }\end{array}$ \\
\hline PS, early 40s, English teacher & Moderator, member of PXB elite. & Videography interview, 2008/2009. \\
\hline Tux, 40s, IT professional & Moderator, member of PXB elite. & Videography interview, 2008/2009. \\
\hline Philip, 40s, lawyer & Moderator, member of PXB elite. & Videography interview, 2008/2009. \\
\hline
\end{tabular}




\begin{tabular}{|c|c|c|}
\hline \multicolumn{3}{|c|}{ Table 2: The mechanisms of normalization in the PXB community } \\
\hline $\begin{array}{c}\text { Normalization Mechanism } \\
\text { (Adapted from: May and } \\
\text { Finch, 2009) }\end{array}$ & $\begin{array}{l}\text { How it manifests in the PXB } \\
\text { Community }\end{array}$ & $\begin{array}{l}\text { Examples from dataset } \\
\text { (all quotes from PXB discussion forums unless indicated otherwise) }\end{array}$ \\
\hline $\begin{array}{l}\text { Coherence (what is the } \\
\text { work?): the sense-making } \\
\text { work that people do } \\
\text { individually and collectively } \\
\text { when they are faced with the } \\
\text { problem of operationalizing } \\
\text { new practices. }\end{array}$ & $\begin{array}{l}\text { The common goal of a piracy-free } \\
\text { community: Community founders } \\
\text { envisioned a practice that was new to } \\
\text { the Brazilian context (legal gaming), } \\
\text { and engaged in individual and } \\
\text { collective sense-making work with } \\
\text { early members to determine that } \\
\text { implementing this new practice was } \\
\text { important. Later, the community } \\
\text { works in establishing coherence to } \\
\text { make sense of legal and illegal } \\
\text { gaming in the Live platform. }\end{array}$ & $\begin{array}{l}\text { "More people started to come to the community with the growth of Xbox } 360 \text { in } \\
\text { Brazil. They wanted information, but information related to using pirate games, and } \\
\text { this was a banished topic. In the beginning, people found it strange, but they started } \\
\text { to read the instructions, liked the community, and stayed. So people started to like } \\
\text { the community and it became bigger" (Raphael, moderator, interview, 2013). } \\
\text { "My first post on PXB was a declaration of adoption of the original games and a } \\
\text { repudiation of piracy (a long post by the way) - repudiation of the piracy I had } \\
\text { enjoyed on PS1 and PS2. I have considered this [community] a family ever since." } \\
\text { "[...] people like us, who are fanatical for games and technology, offer ideas, debate, } \\
\text { defend certain opinions with conviction, we are always reading news about Xbox, } \\
\text { Ps4, PCs." }\end{array}$ \\
\hline $\begin{array}{l}\text { Cognitive participation (who } \\
\text { does the work?): the relational } \\
\text { work that people do to build } \\
\text { and sustain a community that } \\
\text { is responsible for working to } \\
\text { implement a new practice. }\end{array}$ & $\begin{array}{l}\text { Telling right from wrong, and original } \\
\text { from pirate: Community members } \\
\text { start to organize themselves and } \\
\text { others to collectively contribute to the } \\
\text { work involved in new practices. This } \\
\text { involves discussions of how to relate } \\
\text { to gamers who engage in illegal } \\
\text { gaming, and working to ensure that } \\
\text { gamers believe it is right for them to } \\
\text { be involved, and that they can make a } \\
\text { valid contribution to it. }\end{array}$ & $\begin{array}{l}\text { "And even all these obstacles are just another excuse to adhere to piracy ... In my } \\
\text { opinion those who use pirated games use them because they want, regardless of the } \\
\text { justifications they may have." } \\
\text { "This is unnecessary [attacking users who bring up piracy] and leads to animosities } \\
\text { and considerable loss of time. It is not because one started on the wrong foot that he } \\
\text { should be immediately banished. Be friendly ... you can reply with something like } \\
\text { this: "Please, consider that PXB does not support the use of pirated products. Take } \\
\text { your question to another forum where this practice is accepted." And then report the } \\
\text { topic so that moderators can take appropriate action. Of course, it is not necessary to } \\
\text { follow this exact response every single time, but try to be polite in your answer. If } \\
\text { such a user shows that he's childish and continues to post about piracy or wants to } \\
\text { irritate you, a serious user of PXB, don’t waste your time: post only these two } \\
\text { words: Reported topic. Report to us immediately, so that the topic is locked/deleted } \\
\text { and its creator is promptly notified, and may even suffer retaliations. Just remember: } \\
\text { many of those who started in piracy today learned through their mistakes and now } \\
\text { make use of original material. So harsh and thoughtless answers might make us lose } \\
\text { a future user of original games and even worse, a possible good member of PXB.” }\end{array}$ \\
\hline
\end{tabular}




\begin{tabular}{|c|c|c|}
\hline & & $\begin{array}{l}\text { "Man, now that you have come to the good side, have fun, enjoy it. In the next MS } \\
\text { update, these folks [who play pirate] will be gone for a month and you will be cool. I } \\
\text { do not deny that temptation is great. But at least I play without having to worry } \\
\text { about anything. Today I even had a YouTube update, and I updated without even } \\
\text { thinking. Can these guys do that???" } \\
\text { "You don't have to be sorry if you want to come to the good side of the force [...], } \\
\text { we are waiting you with open arms" }\end{array}$ \\
\hline $\begin{array}{l}\text { Collective Action (how does } \\
\text { the work get done?): the } \\
\text { operational work that people } \\
\text { do to enact new practices. }\end{array}$ & $\begin{array}{l}\text { Advancing towards legal gaming } \\
\text { through collective effort: Collective } \\
\text { action occurred through assisting } \\
\text { players on how to switch from piracy } \\
\text { to legal gaming practices; and } \\
\text { working to reduce taxes for legal } \\
\text { games in Brazil. }\end{array}$ & 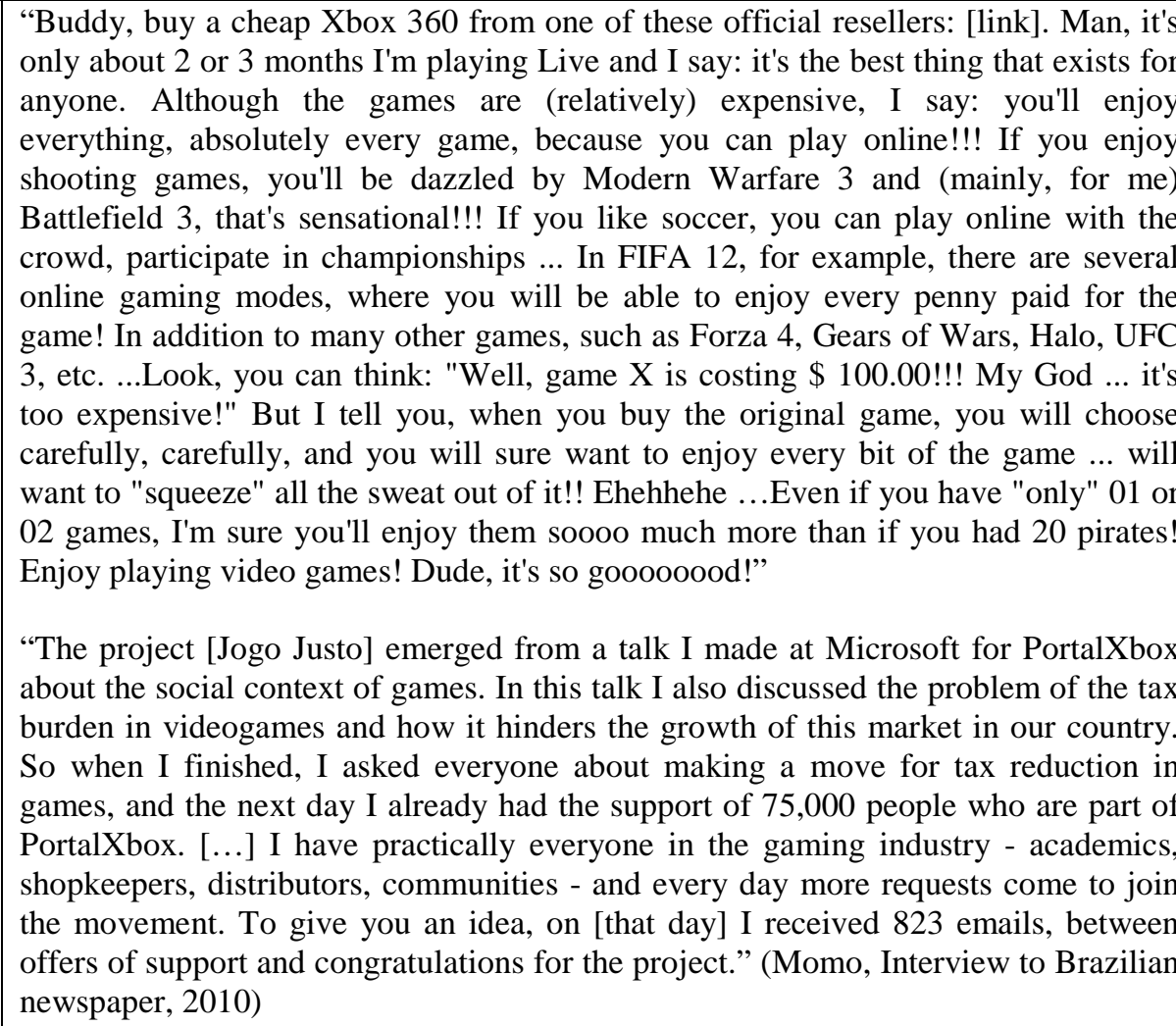 \\
\hline $\begin{array}{l}\text { Reflexive monitoring (how is } \\
\text { the work understood?): the } \\
\text { appraisal work people do to } \\
\text { assess and understand the }\end{array}$ & $\begin{array}{l}\text { The continuous evaluation of a } \\
\text { piracy-free ideal: Reflexive } \\
\text { monitoring occurred through the years } \\
\text { as individually and collectively, }\end{array}$ & $\begin{array}{l}\text { "For good and for worse, times have changed. Games continued to be pirated and } \\
\text { companies continued to try to protect their products however they could. Not } \\
\text { infrequently, at the players' expense. If in the past there were codes, there are now } \\
\text { games that need to be connected to the official servers all the time. It is perfectly OK }\end{array}$ \\
\hline
\end{tabular}




\begin{tabular}{|l|l|l|}
\hline $\begin{array}{l}\text { ways that a new set of } \\
\text { practices affect them and } \\
\text { others around them. }\end{array}$ & $\begin{array}{l}\text { members appraised their work and its } \\
\text { outcomes, and adjusted their work to } \\
\text { oppose piracy in the Brazilian market. }\end{array}$ & $\begin{array}{l}\text { for producers and developers to try to defend themselves against piracy - after all, } \\
\text { they are businesses, not charities, as Cliff Bleszinski said. Games cost millions of } \\
\text { dollars to make, and every programmer, artist, producer, and tester needs to be } \\
\text { paid.” }\end{array}$ \\
& $\begin{array}{l}\text { "That is why this is called a DISCUSSION FORUM. If we censor certain discussion } \\
\text { themes because of conjectures that users do not have the maturity to talk about them } \\
\text { or are easily influenced by a practice that, between you and me, is beyond old, } \\
\text { Good, then we'll have to ban a lot of people. I am in favor of repressing the practice } \\
\text { and posts that include tutorials, links, etc. What I do not agree with is banishing the } \\
\text { theme from the discussions." } \\
\text { "Today the community manages itself. When users see that there's someone outside } \\
\text { the norm, they will take care of it. We don't need many moderators to point fingers } \\
\text { or execute moderating actions, so I can keep a small team of three moderators and } \\
\text { they'll take care of everything." (Raphael, moderator turned manager, interview } \\
\text { 2017) }\end{array}$ \\
&
\end{tabular}

